Innovation and Trade in the Presence of Credit Constraints

Reto Föllmi, Stefan Legge, Alexa Tiemann

January 2015 Discussion Paper no. 2015-03 


$\begin{array}{ll}\text { Editor: } & \text { Martina Flockerzi } \\ & \text { University of St.Gallen } \\ & \text { School of Economics and Political Science } \\ & \text { Department of Economics } \\ & \text { Bodanstrasse 8 } \\ & \text { CH-9000 St. Gallen } \\ & \text { Phone } \quad+41712242325 \\ & \text { Fax } \quad+41712243135 \\ & \text { Email seps@unisg.ch } \\ & \text { School of Economics and Political Science } \\ & \text { Department of Economics } \\ & \text { University of St.Gallen } \\ & \text { Bodanstrasse } 8 \\ \text { Publisher: } & \text { CH-9000 St. Gallen } \\ & \text { Phone +41 71 224 23 25 } \\ & \text { Fax }+41712243135 \\ & \text { http://www.seps.unisg.ch }\end{array}$




\title{
Innovation and Trade in the Presence of Credit Constraints ${ }^{1}$
}

\author{
Reto Föllmi, Stefan Legge ${ }^{2}$, Alexa Tiemann ${ }^{3}$
}

Author's address:

Prof. Dr. Reto Föllmi

Swiss Institute for International Economics and Applied

Economic Research (SIAW-HSG)

Bodanstrasse 8

$\mathrm{CH}-9000$ St.Gallen

Phone +41712242269

Fax $\quad+41712242298$

Email_reto.foellmi@unisg.ch

Website www.siaw.unisg.ch

\footnotetext{
${ }^{1}$ For helpful comments, we are grateful to Johannes van Biesebroeck, Peter Eppinger, Roland Hodler, Nathan Nunn, Manuel Oechslin, Lukas Schmid, Uwe Sunde, as well as seminar participants at Harvard, St.Gallen, the 2014 European Trade Study Group in Munich, Midwest International Trade Meeting in Lawrence, Warsaw International Economic Meeting, SNF/CEPR Conference on International Trade in Ascona, Congress of the Swiss Society of Economics and Statistics in Bern, Spring Meeting of Young Economists in Vienna, the 2013 AEL Conference in Munich, and the 2012 Sinergia Workshop in Hurden.

${ }^{2}$ Stefan Legge: University of St.Gallen and UC Berkeley, 530 Evans Hall \#3880, Berkeley, CA 94720, Email: slegge@berkeley.edu.

${ }^{3}$ Email: alexa.tiemann@unisg.ch.
} 


\begin{abstract}
This paper examines how trade liberalization affects investments in R\&D at the firm level. We provide a model with entrepreneurs differing in their wealth endowment, causing them to rely differently on external funds. In the presence of capital market imperfections, this implies heterogeneous access to external funds such that poor entrepreneurs run smaller firms, are less likely to invest in R\&D, and more likely to exit the market. Decreasing trade costs resulting from tariff reductions exacerbate these characteristics. Using firm-level panel data on seven Latin American countries for 2006 and 2010, we find support for our theoretical predictions. While recent studies emphasize a positive impact of trade liberalization on firms' productivity-enhancing activities, we provide novel evidence showing that financial constraints can impair the effect on R\&D efforts. These results suggest that imperfect capital markets can prevent welfare gains from trade liberalization to materialize.
\end{abstract}

\title{
Keywords
}

Financial constraints, innovation, trade liberalization.

\section{JEL Classification}

$\mathrm{F} 14, \mathrm{O} 12, \mathrm{O} 16$. 


\section{Introduction}

A large body of trade literature provides empirical support for the superior performance characteristics of exporting firms relative to non-exporters (Bernard and Jensen, 1999; Bernard et al., 2007). Recent research has focused on one particular explanation for this superiority. There appears to be a complementarity between firms' exporting status and their investments in productivity-enhancing activities. Investigating this observation, researchers followed a key insight by Schmookler (1966) that inventors channel their efforts into those lines of activity with high prospective profits. If the size of any market that firms operate in becomes larger, potential profits increase and so do firms' R\&D-related efforts. This can be linked to trade policy in the sense that any removal of trade frictions effectively enlarges the size of the market firms are serving. Operating in a globalized market makes it more profitable for firms to invest in $R \& D$ as a means to remain competitive and capture a large share of the enlarged market.

We examine both theoretically and empirically the decision of firms, who operate under financial constraints, to invest in $R \& D$ when tariffs change. We believe this setup to be of particular interest as financially constrained firms cannot capture the increased market size due to trade liberalization when credit constraints restrict their ability to adjust the production. Previous research by Banerjee (2004) as well as Banerjee and Duflo (2013) document the importance of credit constraints for small and medium-sized enterprises. In a closed economy setup, Gorodnichenko and Schnitzer (2013) show that financial frictions affect a firm's decision to invest in innovative activities. In our context where trade liberalization can worsen access to finance for small firms we derive similar results. Poorer entrepreneurs are particularly susceptible to the ramifications of trade openness. This adds to previous findings by Aghion, Caroli and García-Peñalosa (1999) showing that in the presence of limited borrowing capacities, the distribution of wealth affects firms' production possibilities.

Several recently published studies document empirically the so-called market size effect on innovation with respect to trade liberalization. Bernard, Jensen and Schott (2006) show that U.S. manufacturing industries exhibit strong productivity growth after experiencing large declines in trade costs. Atkeson and Burstein (2010) provide a general equilibrium model and show how trade liberalization affects firms' decision to invest in R\&D. For a sample of Argentinean firms, Bustos $(2011 a, b)$ documents that tariff reductions were associated with technology upgrading. Aw, Roberts and Winston (2007) as well as Aw, Roberts and Xu 
(2011) also consider research investments and exporting behavior as joint decisions. Using plant-level data from Taiwan they find evidence that both activities increase productivity. ${ }^{1}$ Lileeva and Trefler (2010) draw on Canadian firm-level data and provide evidence that after a reduction in tariff rates, firms that started exporting or exported more increased their productivity and became more innovative.

This literature, however, has been largely silent about firm-level responses to trade liberalization in the presence of imperfect capital markets. Traditional trade theory assumes that resources are allocated efficiently across firms by means of a well-functioning capital market. While this takes into account that firms face upfront expenses for production and R\&D efforts, it abstracts from capital market imperfections found in most developing economies. ${ }^{2}$ Recent advances in trade theory incorporate credit constraints. Foley and Manova (2014) provide a survey of this literature. In particular, research has shown that lacking access to capital can preclude some firms from engaging in trade although this could be profitable (Manova, 2013; Manova, Wei and Zhang, 2014). This adverse effect of financial frictions is particularly severe in sectors with high dependency on external finance. ${ }^{3}$

In our theoretical model we follow previous work by Föllmi and Oechslin $(2010,2013)$. In particular, we assume that entrepreneurs differ in their initial wealth endowments. As a result, poor firm owners must rely on external finance for their business activities. In doing so, they use their local monopoly power as a collateral. However, after trade liberalization the decline in mark-ups as well as the rise in interest rates limit their ability to borrow. While trade liberalization would induce them to adjust their production, investments are restricted by financial constraints. This gives rise to two results. First, quality-upgrading is limited in the sense that we observe fewer investments in R\&D among financially constrained firms exposed to tariff reductions. Second, severely credit-constrained firms are likely to leave the market after trade liberalization.

In addition to our theoretical work, we examine empirically the responses of firms to trade liberalization conditional on a number of firm and market characteristics that may

\footnotetext{
${ }^{1}$ Verhoogen (2008) finds similar evidence in a panel data set on Mexican manufacturing plants. In a related study, Costantini and Melitz (2008) build a dynamic model of plant-level adjustments to trade liberalization capturing the joint innovation and exporting decision, selection into exporting, and learning-by-exporting.

${ }^{2}$ Aghion et al. (2010) analyze the implications of financial frictions with respect to volatility and growth. They provide theoretical and empirical support for adverse effects of credit constraints on long-term investments.

${ }^{3}$ Rajan and Zingales (1998) show that due to technological reasons a country's financial underdevelopment affects different sectors differently.
} 
explain heterogeneous behavior. We focus on the combined effect of financial constraints and liberalization on market exit as well as various R\&D-related activities. The latter are measured by product and process innovations as well as filed patents. For our empirical analysis we use a novel data set on seven Latin American countries for the years 2006 and 2010. We merge firm survey data from the World Bank's Enterprise Surveys with tariff data from the World Integrated Trade Solution database. The former contains a large set of variables on firm characteristics while the latter allows us to apply a precise measure of treatment for each firm on the four-digit ISIC classification level. Our data set is preferable to those used in many other studies as it contains direct measures of innovation and financial constraints. Thus we do not have to rely on proxies for outcome and treatment variables in the econometric specification.

Although tariff reductions in our data have a positive impact on productivity-enhancing activities (such as R\&D) we find evidence showing that credit constraints partly drive firms' responses to liberalization. The results indicate that tariff cuts worsen small and mediumsized firms' access to finance. Financially constrained firms experience substantial declines in annual sales if they were subject to tariff reductions. We further find that market exit is more pronounced among financially constrained firms. Our estimates suggest that a tariff reduction for these firms is associated with a significant increase in the probability of leaving the market. Moreover, we find that among surviving firms, those reporting financial constraints in the initial period are associated with a lower probability of introducing innovative products or production processes if they are subject to trade liberalization. These findings are in line with our theory and shown to be robust to the inclusion of various control variables as well as country- and industry-fixed effects. Moreover, the results are not driven by any single country or by an underlying correlation of firm size and credit constraints. Furthermore, the results are similar when using simple average or weighted average tariff rates and the impact is generally magnified in less developed countries.

Our work adds another dimension to the literature on how financial constraints distort reallocations within firms after trade liberalization. In this we contribute to recent studies by Hsieh and Klenow (2009) as well as Song, Storesletten and Zilibotti (2011) who examine how credit market frictions lead to resource misallocation in low-income countries. At the macro level, Caselli $(2012,2013)$ shows that among developing countries gains from trade openness depend inversely on the degree of wealth inequality prior to liberalization. Closely related 
to our work, Chesnokova (2007) presents a model with necessary investments and credit constraints. In this model, specialization after trade liberalization can be welfare-reducing if specialization in agriculture affects the wealth distribution such that credit constraints become more binding. Amiti and Weinstein (2011) examine firm-specific shocks to trade finance supply in the setting of Japan's systemic crises from 1990 thought 2010. Their findings suggest that liquidity shocks hurt firms' export growth even more than domestic sales.

We also draw on previous research on international trade and product choice. Acemoglu and Zilibotti (2001) document that firms in poor economies generally tend to produce less innovative goods. Hence these firms typically adjust their production after liberalization (Fieler, Eslava and Xu, 2014). In particular, exporting firms in low-income countries have been shown to produce higher-quality goods for export than for the domestic market (Verhoogen, 2008). However, producing superior quality requires R\&D investments. Hence, innovative firms may be exposed to higher survival risks if they do not retain diversified sources of finance (Fernandes and Paunov, 2014). Our paper adds to these studies, suggesting that imperfect capital markets can be a source of market exit and limited product upgrading.

The findings of our study can also be linked to research on the determinants of gains from trade. In the past decade, several studies revived the idea that countries specialize according to their comparative advantages and benefit from trade because they have access to different technologies (Eaton and Kortum, 2012). Simultaneously, trade theory has been enriched by the idea of heterogeneous firms within countries. Following the seminal work by Melitz (2003), much research has analyzed the differential effects of trade liberalization across firms and workers. Moreover, there is an ongoing discussion about the magnitude of welfare gains from trade. While Eaton and Kortum (2002) as well as Arkolakis, Costinot and Rodríguez-Clare (2012) find only modest gains, Caliendo and Rossi-Hansberg (2012) as well as Melitz and Redding (2014) argue that trade openness can induce a reorganization of production which raises domestic productivity and may cause welfare gains from trade to become arbitrarily large. Average welfare effects, however, shroud large heterogeneity in welfare gains across countries, in particular the mixed experiences of developing countries (Greenaway, Morgan and Wright, 2002; Galor and Mountford, 2008). In this regard, the question arises under which circumstances heterogeneous responses and financial constraints 
at the firm level can limit overall gains from trade.

Finally, our study is related to previous research on trade liberalization and income inequality (Goldberg and Pavcnik, 2007) as well as the dispersion of mark-ups across firms (Epifani and Gancia, 2011). Antras and Caballero (2009) examine how goods and financial markets integration interact. They find that trade integration leads to capital inflow for developing countries. Thus in less financially developed economies, trade and capital mobility are complements. Financial frictions tend to depress the rental rate of capital but in the presence of cross-sectoral heterogeneity in financial dependence, specialization allows developing countries to partially circumvent these frictions. Thus long-run effects of trade liberalization appear to crucially depend on the level of financial frictions.

The different strands of the literature lead to our hypothesis that access to finance plays a key role in determining firm-level responses to trade liberalization. We investigate this relationship by considering two observable firm decisions: market exit and productivityenhancing activities. Our theoretical model predicts less product-upgrading and increased market exit among credit-constrained firms that are subject to trade liberalization. The empirical results in our paper support these predictions. Adjustments after liberalization appear to be impaired at the firm level if access to finance is limited.

The remainder of the paper is organized as follows. In Section 2 we present a simple theoretical model to illustrate the impact of capital market frictions in a setting of heterogeneous firms facing trade liberalization. Section 3 describes our data set and provides descriptive statistics. Our empirical strategy as well as the results are shown in Section 4. The final section concludes and discusses policy implications.

\section{Theory}

\subsection{The Setup}

The model, in particular the design of the credit market, follows Föllmi and Oechslin (2010). We consider a static economy, populated by a continuum of (potential) entrepreneurs with population size 1 . The individuals are heterogeneous with respect to their initial capital endowment $\omega_{i}, i \in[0,1]$. The capital endowments are distributed according to the distribution function $H(\omega)$. Aggregate capital endowment, $\int_{0}^{\infty} \omega d H(\omega)$, is denoted by $K$. 
Each individual owns a specific skill (a "business idea") that makes him a monopoly supplier of a single differentiated good. All goods are produced with a simple technology that requires physical capital as the only input into production. Following the trade literature (e.g., Melitz (2003)), starting production needs a fixed outlay of $f$ capital units. Formally, the production function reads $y_{i}=a\left(k_{i}-f\right)$ where $a$ is a productivity parameter and $y_{i}$ and $k_{i}$ denote, respectively, output and capital invested. In addition to the initial business idea, the entrepreneur has the option to invest in $R \& D$ which raises the quality of the product from level 1 to $q>1$, to model it in the most simple way. ${ }^{4}$ Investment into quality upgrading requires additional $f(q-1)$ capital units.

The individuals' utility function takes the familiar CES-form and consumers treat the two different quality versions of a good $j$ as perfect substitutes

$$
U=\left[\int_{0}^{1}\left(c_{1 j}+q c_{q j}\right)^{(\sigma-1) / \sigma} d j\right]^{\frac{\sigma}{\sigma-1}}, \sigma>1
$$

where $c_{\cdot j}$ denotes consumption of good $j$ at quality level 1 or $q$. Each individual $i$ maximizes the objective function (1) subject to the budget constraint

$$
\int_{0}^{1}\left(p_{1 j} c_{1 j}+p_{q j} c_{q j}\right) d j=m\left(\omega_{i}\right)
$$

where $p_{j}\left(q_{j}\right)$ is the price of good $j$ (for quality 1 or $q$ ) and $m\left(\omega_{i}\right)$ refers to individual $i$ 's nominal income depending on the initial capital endowment, $\omega_{i}$.

Since both quality levels have the same marginal costs in production, we may simplify the exposition assuming that $p_{1 j} \leq p_{q j} / q$. Under these conditions and if only one quality per good $j$ is consumed, individual $i$ 's demand for good $j$ reads

$$
c_{j}\left(m\left(\omega_{i}\right), p_{j}\left(q_{j}\right), q_{j}\right)=q_{j}^{-1}\left(\frac{p_{j}\left(q_{j}\right) / q_{j}}{P}\right)^{-\sigma} \frac{m\left(\omega_{i}\right)}{P}
$$

where $P \equiv\left[\int_{0}^{1} p_{1 j}^{1-\sigma} d j\right]^{1 /(1-\sigma)}$ is the familiar CES price index.

Individuals take the equilibrium borrowing rate as given but there may be credit-rationing. The reason for an upper bound on borrowing is the imperfect enforcement of credit contracts.

\footnotetext{
${ }^{4}$ Empirical support for the effect of trade liberalization on product quality upgrading is provided by Fernandes and Paunov (2013).
} 
Following Foellmi and Oechslin (2013), we assume that - in case of default - borrower $i$ loses only a fraction $\lambda \in(0,1]$ of the current firm revenue, $p\left(y_{i}, q_{i}\right) y_{i}$. The parameter $\lambda$ indicates how well credit contracts can be enforced. If $\lambda$ is close to zero, the borrowers do not lose much when they do not honor their debt. In that case, the incentives for lenders are small to provide high levels of external finance.

The lender will give credit only up to the point where the borrower still has an incentive to pay back. Formally, the size of the credit cannot exceed $\lambda p\left(y_{i}, q_{i}\right) y_{i} / r$, where $r$ denotes the interest rate. As there is no default in equilibrium, the borrowing rate $r$ must be the same for all agents. To calculate the amount of credit needed, note that you need $k_{i}=y_{i} / a+f$ capital units to produce $y_{i}$. To produce at quality level $q_{i}$ additional $f\left(q_{i}-1\right)$ capital units are needed. With equity $\omega$, you need to borrow $y_{i} / a+f+f\left(q_{i}-1\right)-\omega$ capital units. Taking that into account, borrower $i$ will repay the debt if

$$
\lambda p\left(y_{i}, q_{i}\right) y_{i} / r \geq y_{i} / a+f q_{i}-\omega_{i}
$$

\subsection{Effects of International Trade}

We assume that the home economy is a developing country (the "South"). The trading partner, the rest of the world, is an advanced economy and referred to as the "North". Trade costs take the usual "iceberg" formulation and we assume that $\tau \geq 1$ units of a good have to be shipped in order for one unit to arrive at the destination. As in Föllmi and Oechslin (2013) we assume that the North differs from the South in that its markets function perfectly. In particular, the northern credit market is frictionless so that there are no credit constraints. Moreover, in the North, each variety in both qualities is produced by a large number of firms so that the northern goods market is perfectly competitive. Regarding access to technology and preferences, there are no differences between the two regions. Further, for the sake of simplicity, the North produces the same spectrum of goods as the South does.

These assumptions imply that all northern firms charge a uniform price for a given quality, equal to the marginal cost. We normalize the northern price level for products of quality $q$ to one. This normalization implies that all goods prices in the North (as well as the northern marginal cost) are also equal to one.

What does this mean for the market structure in the South? Although entrepreneur $i$ has a domestic monopoly, he faces a competitive fringe by Northern producers and cannot 
set a price above $\tau$ when supplying the high quality, and $\tau / q$ when supplying the low quality. We assume that the market is sufficiently integrated such that all entrepreneurs face the competitive fringe (for cases with intermediate values of $\tau$, see Föllmi and Oechslin (2013)).

We are left to determine the borrowing rate. Since we are looking at an equilibrium in which a positive mass of entrepreneurs is credit-constrained and cannot serve the whole market, the economy imports goods from abroad. This, in turn, implies that there must be positive aggregate exports with balanced trade in a static model. The marginal product of capital equals $a$. There if an entrepreneur exports one unit of an arbitrary good, this needs $\tau / a$ units of capital and generates an income of 1 . The entrepreneur compares the return from exporting $(\tau / a)^{-1}$ with the returns when acting as lender on the domestic market. Arbitrage requires therefore that the domestic borrowing rate $r$ must equal $a / \tau$.

For credit-constrained firms, the maximum output $\bar{y}$ is determined by $\lambda p\left(\bar{y}, q_{j}\right) \bar{y} / r \geq$ $\bar{y} / a+f q_{j}-\omega$, where we use (4) and $p\left(\bar{y}, q_{j}\right)=\tau q_{j} / q$. Note that the price the firm can charge is given by $p\left(\bar{y}, q_{j}\right)=\tau q_{j} / q$. That is, if the firm invests into quality upgrade it can charge a price of $\tau$, otherwise the price is $\tau / q$. We get $\bar{y}=a\left(\omega-f q_{j}\right) /\left(1-\lambda \tau^{2} q_{j} / q\right)$. Firms not facing the credit constraint serve the whole market. Using (3) and taking into account that high-quality industry output is given by $y_{\max }=q_{j}^{-1}(\tau / q)^{-\sigma} P^{\sigma-1} Y$, where $P^{\sigma-1} Y$ is uniquely determined in the macroeconomic equilibrium (see Foellmi and Oechslin, 2013). To sum up, domestic output in sector $j$ is given by

$$
y_{j}=\min \left\{\frac{a\left(\omega-f q_{j}\right)}{1-\lambda \tau^{2} q_{j} / q}, q_{j}^{-1}(q / \tau)^{\sigma} P^{\sigma-1} Y\right\}
$$

Note that firm output increases in initial wealth for the credit-constrained, poorer entrepreneurs. The reason is the credit market imperfection: an increase in $\omega$ means an entrepreneur has more resources to invest and - in addition - it allows for higher borrowing since the entrepreneur has more own collateral which he would lose by not honoring the credit contract. In that sense, $\left(1-\lambda \tau^{2} / q_{j}\right)^{-1}$ may be interpreted as credit multiplier. Note that the credit multiplier falls and the firm size of constrained entrepreneurs necessarily falls if $\tau$ decreases. This is due to two effects: First, a decrease in trade costs lowers the maximum price monopolists can charge which erodes profits serving as collateral. Second, a lower $\tau$ increases the borrowing rate $r=a / \tau$, since exporting is more attractive. Higher borrowing rates make it more difficult that equation (4) holds. 


\subsection{Decision on Exit and R\&D}

An entrepreneur seeks to maximize his nominal income. It is given by revenues minus interest payments or $p\left(y_{i}, q_{i}\right) y_{i}-r\left(y_{i} / a+f q_{i}-\omega_{i}\right)=(1-\lambda) p\left(y_{i}, q_{i}\right) y_{i}$, for active credit-constrained entrepreneurs (using (4)). The entrepreneur compares the entrepreneurial income with and without quality upgrading, $m_{e q}$ and $m_{e}$, respectively, and the income he would get if he decides to exit and become a lender, earning $m_{l} \equiv r \omega=a \omega / \tau$. Thus, he maximizes nominal income

$$
\max _{\{e, q\}}\left\{m_{e q}(\omega), m_{e}(\omega), m_{l}(\omega)\right\}
$$

where

$$
\begin{aligned}
m_{e q}(\omega) & =(1-\lambda) \tau \frac{a(\omega-f q)}{1-\lambda \tau^{2}} \\
m_{e}(\omega) & =(1-\lambda) \tau \frac{a(\omega-f)}{q-\lambda \tau^{2}} \\
m_{l}(\omega) & =\frac{a \omega}{\tau} .
\end{aligned}
$$

To have an interesting problem where all three occupations $(l, e, e q)$ are possible outcomes, we make the following assumption on trade costs, which is necessary and sufficient such that occupation $e$ exists.

Assumption 1. We assume the following condition to hold: $\tau^{2}>1+q$

Given Assumption 1 we see directly that $m_{e q}^{\prime}(\omega)>m_{e}^{\prime}(\omega)>m_{l}^{\prime}(\omega)$. On the other hand $m_{e q}(0)<m_{e}(0)<m_{l}(0)=0$. Hence, the poorest agents will choose to become lenders, for medium levels of $\omega$ agents become entrepreneurs without investing into quality upgrading, and for high levels of $\omega$ the entrepreneurs invest in $R \& D$ as well. The critical wealth level $\omega_{1}$ where agents are indifferent between becoming entrepreneur or lender equals $\omega_{1}=f(1-\lambda) \tau^{2} /\left(\tau^{2}-q\right)$. The critical wealth level $\omega_{2}$ where agents are indifferent between investing into quality or not investing equals $\omega_{2}=f\left(1+q-\lambda \tau^{2}\right)$. Obviously, occupation $e$ exists only iff $\omega_{2}>\omega_{1}$. It is easy to check (by insertion) that $\omega_{2}>\omega_{1}$ holds iff $\tau^{2}>1+q$.

Intuitively, the product market imperfections make entrepreneurship more profitable than being lender. As entrepreneurship entails fixed costs, this option is only preferred to being lender if the firm size is large enough. A fortiori this argument holds for investment in R\&D. Since firm size and wealth are positively correlated with each other, poorer entrepreneurs are more likely to become lenders and are less likely to invest into high-quality production. 
- Figure 1 about here -

Individuals with an initial endowment below $\omega_{1}$ decide to be lenders while those with a larger endowment become entrepreneurs. If the initial endowment is larger than $\omega_{2}$, individuals become entrepreneurs and invest in quality upgrading.

The following Propositions state that financially constrained firms are more likely to exit the market and less likely to invest in $\mathrm{R} \& \mathrm{D}$ when trade liberalization occurs.

Proposition 1. A decrease in trade costs $\tau$ induces severely credit-constrained firms to exit the market.

Proof. The derivative of $\omega_{1}$ with respect to $\tau$ reads $\partial \omega_{1} / \partial \tau=-2 f q(1-\lambda) \tau /\left(\tau^{2}-q\right)^{2}<0$. A decrease in $\tau$ increases the range of entrepreneurs who choose to become lenders.

Proposition 2. A decrease in trade costs $\tau$ reduces investment into quality upgrading by financially constrained firms.

Proof. The minimum wealth level to invest in quality $\omega_{2}=f\left(1+q-\lambda \tau^{2}\right)$ decreases in $\tau$. A lower level of $\omega_{2}$ reduces the range of entrepreneurs who invest in $R \& D$.

Things look different for unconstrained entrepreneurs. Trade liberalization raises, ceteris paribus, the incentives to invest into quality upgrading. The reason is that for unconstrained entrepreneurs the high-quality output increases when trade $\operatorname{costs} \tau$ fall, as market demand is higher with lower prices and eventually higher real income due to lower price distortions. A financially constrained entrepreneur, instead, is incapable to serve the full market because of limited access to credit. This market-size effect makes the option to invest in R\&D more attractive for the unconstrained entrepreneur. The income of a financially unconstrained entrepreneur, producing high-quality products, is given by

$$
(q / \tau)^{\sigma-1} P^{\sigma-1} Y-(a / \tau)\left(q^{-1}(q / \tau)^{\sigma} P^{\sigma-1} Y / a+f q-\omega\right)
$$

Income when producing low-quality is given by

$$
(q / \tau)^{\sigma-1} P^{\sigma-1} Y-(a / \tau)\left((q / \tau)^{\sigma} P^{\sigma-1} Y / a+f-\omega\right)
$$

The difference between the two expressions equals $(a / \tau)\left(q^{-1}(q / \tau)^{\sigma} P^{\sigma-1} Y / a-f\right)(q-1)$. Hence, the incentive to invest in high quality rises when $\tau^{-\sigma} P^{\sigma-1} Y$ is larger. 
Gross capital supply equals demand in the capital market equilibrium condition,

$$
\begin{aligned}
K & =\left[1-G\left(\omega_{3}\right)\right]\left[q^{-1}(q / \tau)^{\sigma} P^{\sigma-1} Y / a+f q\right] \\
& +\int_{\omega_{2}}^{\omega_{3}}\left[\frac{\omega-f q}{1-\lambda \tau^{2}}+f q\right] d G(\omega)+\int_{\omega_{1}}^{\omega_{2}}\left[\frac{\omega-f}{1-\lambda \tau^{2} / q}+f\right] d G(\omega),
\end{aligned}
$$

where $\omega_{3}=f q+\left(1-\lambda \tau^{2}\right) q^{-1}(q / \tau)^{\sigma} P^{\sigma-1} Y / a$ denotes the wealth level such that the entire market demand can be served. When $\tau$ falls, the gross capital demand of entrepreneurs falls and more entrepreneurs become lenders. Hence, whenever some entrepreneurs are creditconstrained, $\tau^{-\sigma} P^{\sigma-1} Y$ must rise such that the capital market equilibrium condition holds. (It stays constant if all entrepreneurs are unconstrained.) The key difference to the constrained entrepreneurs is that the output $y_{\max }(q)=q^{-1}(q / \tau)^{\sigma} P^{\sigma-1} Y$ increases when trade $\operatorname{costs} \tau$ fall, as market demand is higher with lower prices and eventually higher real income. A financially constrained entrepreneur, instead, is incapable to serve the full market because of limited access to credit. The rise in firm output makes the option to invest in R\&D more attractive for the unconstrained entrepreneur.

Proposition 3. For firms not facing financial constraints, a decrease in trade costs $\tau$ increases the probability to invest in REDD.

Proof. The income of a financially unconstrained entrepreneur, producing high-quality products, is given by

$$
(q / \tau)^{\sigma-1} P^{\sigma-1} Y-(a / \tau)\left(q^{-1}(q / \tau)^{\sigma} P^{\sigma-1} Y / a+f q-\omega\right)
$$

Income when producing low-quality is given by

$$
(q / \tau)^{\sigma-1} P^{\sigma-1} Y-(a / \tau)\left((q / \tau)^{\sigma} P^{\sigma-1} Y / a+f-\omega\right)
$$

The difference between the two expressions equals $(a / \tau)\left(q^{-1}(q / \tau)^{\sigma} P^{\sigma-1} Y / a-f\right)(q-1)$. The incentive to produce the high quality increases when $\tau^{-\sigma} P^{\sigma-1} Y$ is larger. Gross capital supply equals demand in the capital market equilibrium condition,

$$
\begin{aligned}
K & =\left[1-G\left(\omega_{3}\right)\right]\left[q^{-1}(q / \tau)^{\sigma} P^{\sigma-1} Y / a+f q\right] \\
& +\int_{\omega_{2}}^{\omega_{3}}\left[\frac{\omega-f q}{1-\lambda \tau^{2}}+f q\right] d G(\omega)+\int_{\omega_{1}}^{\omega_{2}}\left[\frac{\omega-f}{1-\lambda \tau^{2} / q}+f\right] d G(\omega) .
\end{aligned}
$$


When $\tau$ falls, the gross capital demand of entrepreneurs falls and more entrepreneurs become lenders. Hence, whenever some entrepreneurs are credit-constrained, $\tau^{-\sigma} P^{\sigma-1} Y$ must rise such that the capital market equilibrium condition holds.

While our assumptions on the utility function could be easily relaxed, the assumption of fixed costs, or more generally increasing returns on the technology side, is key. The basic intuition is quite general: entrepreneurs who are most adversely affected by credit constraints are limited in the entrepreneurial actions. The payoff of the latter typically increases in the market size, however, financially constrained firms cannot grow as easily as unconstrained one due to lack of external funds. Consequently, financially constrained entrepreneurs can take less advantage of market opportunities like trade opening as they make the environment more competitive, hence they are less likely to stay in the market.

\section{Data}

\subsection{Enterprise Surveys and Tariff Data}

The World Bank's Enterprise Surveys (WBES) provide firm survey data for more than 135 countries between 2002-2014. We use data from seven Latin American countries - Argentina, Bolivia, Chile, Colombia, Paraguay, Peru, and Uruguay - where firms were interviewed in 2006 and 2010 with standardized questionnaires. The restriction of our sample to Latin America is to ensure a certain homogeneity of countries. Moreover all of these countries are associated with Mercado Comun del Sur (MERCOSUR), a common market in South America promoting free trade. We included all countries for which data was available as a panel for two years with a moderate sample size. ${ }^{5}$

Each firm was surveyed by means of a standardized questionnaire. This questionnaire covers a wide range of topics, including firm characteristics as well as detailed information on the constraints that firms perceived as an obstacle to their business activity. We use this information to construct variables on the prevalence of credit constraints and the intensity of competition, market exit and several measures of productivity-enhancing activities. Moreover we derive a large set of control variables which are used in all of the regressions. The

\footnotetext{
${ }^{5}$ Note that we excluded Brazilian firms because they were interviewed in different years, 2003 and 2009.
} 
information on financial constraints is derived from a question containing a list of potential obstacles to doing business. In total, the question lists sixteen obstacles, inter alia access to finance, crime, tax administration, tax rates and transportation. Firms are asked which of these obstacles constitute the most binding constraint. This determines our coding of an indicator variable for being financially constrained. The information on firm exit is obtained from the 2010 surveys, which track firms from the first panel round and record information on why firms were unavailable for the second period.

We combine the firm survey data with information on tariff rates from the World Integrated Trade Solution (WITS) database. Using tariff rates from 2006 and 2010 allows us to apply a precise measure of treatment for each individual firm on the four-digit International Standard Industrial Classification (ISIC) level. ${ }^{6}$ Hence, we can clearly identify which firms were subject to trade liberalization (i.e., a reduction of tariff protection for their main product) within each country and sector. We do not, however, have information on the provenance and types of inputs that firms use. Thus we cannot compute firm-specific input tariff levels. However, the survey allows us to identify those firms that use imported inputs and also gives information on whether the inputs were imported directly or indirectly. We use this information as a covariate in our estimations.

We drop all observations from retail and services sectors to focus on the manufacturing sector. In total, our data set contains 5,278 observations from seven countries for the years 2006 and 2010. Among these observations, we have 754 firms which were interviewed in both years (balanced panel). The samples were stratified by industry with the main body of observations being from the textiles sector (35\%), food sector (30\%), and chemicals and paper sector $(22 \%)$. The majority of panel observations were observed in Argentina (187), Chile (191), Columbia (138), and Peru (123). Fewer observations were sampled in Bolivia (20), Paraguay (25), and Uruguay (70).

\subsection{Descriptive Statistics}

Based on the seven countries and two years of observation we have a data set with a total of 5,278 unit observations. Table 1 provides summary statistics for all employed variables in the sample. ${ }^{7}$

\footnotetext{
${ }^{6}$ For each firm the ISIC code is derived from data given in the firm survey.

${ }^{7}$ Further summary statistics are provided in the Appendix.
} 
The statistics indicate that there is considerable variation with respect to most variables across the seven countries. With respect to credit constraints the statistics show that about one in eight firms regards access to finance as the biggest obstacle to their business activity. This aggregate share has not changed between the two observed years 2006 and 2010. Table 1 also provides information on firm characteristics which we use as control variables in the estimations. We have deflated all monetary values, and converted them from local currencies to 2006 US dollars. ${ }^{8}$ Many trade-related variables increase over time. This includes for example the share of firms that are directly importing goods, the share of foreign imported inputs, or the share of exporters. Depending on the country, between $30 \%$ and $70 \%$ of firms engage in productivity-enhancing activities.

Concerning trade liberalization we observe in Table 1 that only Peru and Uruguay lowered their tariffs on average over all industries between 2006 and 2010. In the case of Peru this is due to the United States-Peru Trade Promotion Agreement (PTPA) which was signed on April 12, 2006. According to the Office of the United States Trade Representative, the PTPA provides a secure and predictable legal framework for investors, while strengthening protection for intellectual property, workers, and the environment. Eighty percent of U.S. exports of consumer and industrial products to Peru became duty-free and the remaining tariffs were set to phase out over ten years. ${ }^{9}$ For Uruguay, several bilateral trade agreements with the US were also signed between 2006 and 2008. In contrast, Bolivia shows a significant increase in average tariff rates which may be due to more protectionist policies following the election of president Evo Morales in January of 2006.

We provide information on the seven countries' main trading partners in the Appendix. For all countries in our dataset we observe similar main trading partners. China, the United States, and the European Union account for a large share of both imports and exports. However, there is substantial variation in the trade balance as well as the importance of trade among the seven countries. Boliva, Chile and Paraguay have a very large share of trade in GDP of more than 70 percent. Argentina shows a large surplus in the trade balance while Colombia and Peru have large deficits.

\footnotetext{
${ }^{8}$ Information on the exchange rates are taken from the World Bank Development Indicators.

${ }^{9}$ More details on the PTPA are provided on the website of the United States Trade Representative (www.ustr.gov/trade-agreements/free-trade-agreements/peru-tpa).
} 
For the control variables in our estimation, we only use the 2006 information as well as a variable capturing participation of the firm in the follow-up survey in 2010. There are numerous reasons why firms did not participate in the next round. However, only for nine firms the reason was unknown. Thus attrition is not an issue for our approach when exit is the dependent variable because we can use the full first-period sample. When R\&D-related activities are used as the outcome (which implies that a firm is still operating in 2010) we restrict our sample to a balanced panel of firms. Table 1 provides the respective summary statistics for all relevant variables in this sub-sample.

As noted earlier, follow-up information was not available for many firms for a variety of reasons. This raises the question of how important non-random attrition is in our sample. Overall, the differences with respect to most variables are rather small. Using a simple twosample t-test, we find a few significant differences at the $5 \%$ level. Not surprisingly, the means for credit constraints, competition, market exit, firm size and age are different in the panel and non-panel samples. Some form of non-random attrition can be found in virtually any panel data set and can hardly be corrected for. We use the available information on which firms exited and why (see above reasons) when identifying the effects of trade liberalization and constraints on firms' decisions to engage in R\&D-related activities. In a sample in which the most constrained firms are excluded (because of business failure), only considering surviving firms induces a downward bias of our estimates. This does not change the bottom line of our reasoning. Since we expect a negative effect of liberalization on credit-constrained firms' propensity to invest in quality upgrading, the presence of non-random attrition will cause us to underestimate the effect. This makes it more difficult to find any significant effect.

An important final concern addresses the issue of multi-product firms. As in the related literature, multi-product firms are larger in terms of number of employees and more likely to engage in exporting compared to single product firms. In order to mitigate the problem of multi-product firms, we drop observations where the share of the main product is less than 30 percent. Moreover we control for the share of the main product in all regressions. 


\section{Empirical Results}

As shown in Section 2, reducing trade costs makes it more difficult for small and medium-size firms to borrow capital. In addition, equation 5 shows that output among credit-constrained firms responds negatively to reduced tariff protection. As a result, we expect to see an increase in the probability of market exit among financially constrained firms in sectors with reduced tariffs. Moreover, investments in R\&D-related activities among surviving (financially constrained) firms is expected to decrease.

We use our data set on seven Latin American countries in order to test these predictions. In a first step, we explore empirically whether tariff cuts worsen small firms' access to credit. Furthermore, we test whether annual sales of constrained firms respond negatively to trade liberalization. In the second step, we examine in detail the joint impact of credit constrains and tariff reductions. In particular, we test for the positive effect on market exit as well as the negative impact on $R \& D$ efforts.

\subsection{Trade Openness and Access to Credit}

One of the key insights of our theoretical model is that trade openness can worsen access to finance for some firms. Due to data limitations we cannot provide a structural estimation of the model. However, we can use our data set to test whether the model's main predictions find empirical support. In a first step, we estimate the effect of tariff cuts between 2006 and 2010 on the probability of being credit constrained in 2010. The regression is given by

$$
\begin{aligned}
A_{j, i, c, t}= & \beta_{1} A_{j, i, c, t-1}+\beta_{2} \Delta T_{j, i, c, t}+\beta_{3} \Delta T_{j, i, c, t}^{2} \\
& +\gamma \mathbf{X}_{j, i, c, t-1}+\mu_{c}+\delta_{i}+\varepsilon_{j, i, c, t}
\end{aligned}
$$

where $A_{j, i, c, t-1}$ is a dummy variable indicating whether firm $j$ in industry $i$ and country $c$ reports access to credit being a problem in the first period (2006). $\Delta T_{j, i, c, t}$ is the change in tariff rates at the firm level, calculated as the difference between the two periods 2006 and 2010. Note that due to sufficient sample size we can add country and industry fixed effects to account for unobserved factors not included in the vector of controls $\mathbf{X}_{j, i, c, t}$. The control variables contain firm size, age, foreign ownership, share of main product, and being an exporter. We report the estimates in Table 2. 
The results show strong persistence in credit constraints. Moreover, we observe that large tariff cuts are associated with a significantly higher probability of being credit constrained in 2010. This is in line with findings by Föllmi and Oechslin (2013) who use a Difference-inDifference approach. Small firms' financial health appears to be adversely affected by tariff reductions. Especially large tariff cuts are associated with increased problems in access to finance.

Our model also predicts that among financially constrained firms, output is negatively affected by reductions in trade costs (cf. equation 5). In the second part of Table 2 we test this prediction. Except for obvious changes, the regression we run is similar to the one shown above. Restricting the sample to only those firms which were financially constrained in 2006, however, implies that we have a relatively small number of observations. Nevertheless, we find significant evidence supporting the notion that tariff cuts are adversely related to output in 2010 .

\subsection{Market Exit and Quality Upgrading}

Based on the model in Section 2 we expect firms to respond heterogeneously to tariff reductions. Some firms will continue their business and invest resources into quality-upgrading, some will cut expenses on R\&D efforts, and some will exit the market entirely. Therefore our empirical findings on the joint effects of financial constraints and trade liberalization are split into two parts. We start with an evaluation of the idea that a reduction in tariff protection increases credit-constrained firms' propensity to leave the market as suggested in Melitz and Ottaviano (2008) as well as Föllmi and Oechslin (2010). Second, we estimate the effect of tariff reductions on surviving firms' propensity of developing innovative products and production processes or filing patents.

\subsubsection{Econometric Approach}

Our estimation uses a cross-section of firms where the effect of interest concerns the interaction term on liberalization and credit constraints. The baseline regression is given by 


$$
\begin{aligned}
Y_{j, i, c, t}= & \beta_{1} A_{j, i, c, t-1}+\beta_{2} \Delta T_{j, i, c, t}+\beta_{3} \Delta T_{j, i, c, t}^{2} \\
& +\beta_{4} A_{j, i, c, t-1} \times \Delta T_{j, i, c, t} \\
& +\beta_{5} A_{j, i, c, t-1} \times \Delta T_{j, i, c, t}^{2} \\
& +\gamma \mathbf{X}_{j, i, c, t-1}+\mu_{c}+\varepsilon_{j, i, c, t}
\end{aligned}
$$

where $Y_{j, i, c, t}$ is a dummy variable, capturing the outcome variable obtained from the second period (2010). This can be firm exit, product or process innovation, or filed patents. $A_{j, i, c, t-1}$ again denotes financial constraints of firm $j$ in industry $i$ and county $c$ in the first period (2006). $\Delta T_{j, i, c, t}$ is the change in tariff rates at the firm level, calculated as the difference between the two periods 2006 and 2010. $\mathbf{X}_{j, i, c, t-1}$ is a vector of control variables including firm size, firm age, foreign ownership, degree of competition, share of main product, foreign input share, being a direct importer, being an exporter, and the share of labor cost. ${ }^{10}$ Countryfixed effects are denoted by $\mu_{c}$ while $\varepsilon_{j, i, c, t}$ is the standard error clustered at the country level. ${ }^{11}$ The main effect of interest is given by $\beta_{4}$ and $\beta_{5}$ on the interaction terms. These indicate the differential impact of liberalization on firms that were credit-constrained in the initial period, that is before changes in tariff rates. Note that we check for a non-linear effect by adding the squared term of tariff changes. Since all of outcome variables $Y_{j, i, c, t}$ are dummy variables, we use a probit estimator. ${ }^{12}$ Estimation of the marginal effects at mean values of covariates takes into account prior work by Ai and Norton (2003) as well as Norton, Wang and $\mathrm{Ai}(2004)$.

The standardized questionnaire allows us to draw on two different statistics for market exit as an outcome. First, exit can be defined as business failure which was confirmed in the 2010 survey. Alternatively, following a broader definition, we define exit such that it includes firms which could not be contacted in 2010. This does not contain cases of simple relocation or unwillingness to participate. Instead, this type of market exit may be the result of a dead phone line, a new and unknown postal address, or an unregistered business failure. Note that for our estimations, we entirely use the latter definition. Descriptive statistics indicate that

\footnotetext{
${ }^{10}$ The extent of competition in a given product market has a strong effect on both outcome variables (see, e.g., Melitz and Ottaviano (2008)). Using information from the World Bank surveys, we can address this issue. In particular, we define a competition dummy variable that takes a value of one for firms which reported to have five or more competitors in their market.

${ }^{11}$ Note that we add industry fixed effects in the robustness section. Given the small number of observations in regressions with R\&D-related outcomes, we prefer the specification without industry fixed effects. However, as shown in Table 5, our findings are robust to controlling for industry-specific effects.

${ }^{12}$ When replacing the probit estimator with a logit estimator, the results are very similar.
} 
only three percent of firms left the market using the strict definition. In contrast, with the weaker definition we have about $14 \%$ closing their operations. In order to secure a sufficient number of observations we restrict our estimation to the use of the broader definition of market exit.

The information on financial constraints, $A_{j, i, c, t-1}$, is taken from the World Bank Enterprise Survey (WBES) questionnaire. If a firm nominates access to finance as the single most important obstacle to their business activity, the financial constraint dummy takes a value of one, otherwise zero. ${ }^{13}$ This information is available for both periods 2006 and 2010. In order to identify the joint effect of constraints and liberalization only the 2006 value for the constraint is used in this part of our analysis while the 2010 value is used as an outcome in the previous part.

To identify causal effects, the treatment of tariff liberalization has to be exogenous. Although it is possible that firms influence policies through lobbying it is unlikely that many firms in our sample had sufficient leverage to manipulate national policies. For one thing, the median firm in our data set has only 29 employees. In addition, changes in this policy dimension are often induced by international policies such as free trade agreements or regional organizations. The Peruvian liberalization between 2006 and 2010, for example, was related to the negotiations of the Peru Trade Promotion Agreement with the USA, signed in April 2006. We also provide a simple test for endogeneity by regressing tariff changes on a number of firm characteristics. In particular, we fit the linear regression

$$
\Delta T_{j, i, c, t}=\beta A_{j, i, c, t-1}+\gamma \mathbf{X}_{j, i, c, t-1}+\varepsilon_{j, i, c, t}
$$

where $\Delta T_{j, i, c, t}$ is the tariff change for a specific ISIC code at the four-digit level faced by firm $j$ in industry $i$ and country $c$ between 2006 and 2010. Firm characteristics as of 2006 are summarized as $\mathbf{X}_{j, i, c, t-1}$ and $\varepsilon_{j, i, c, t}$ is the standard error term clustered at the country level. Table 3 provides the estimates.

\section{- Table 3 about here -}

None of the employed firm variables shows a significant effect on tariff changes in the respective ISIC code. In particular, firm size and age in 2006 do not appear to explain

\footnotetext{
${ }^{13}$ The question reads: "You have indicated that several obstacles affect the operation of this establishment. Here is a card with the obstacles I mentioned throughout the interview. Please tell me the three that you think are currently the biggest problem, beginning with the worst of all three."
} 
liberalization patters. Moreover, firms with financial constraints in 2006 are not more likely to be subject to tariff changes. ${ }^{14}$ Nevertheless, we cannot fully rule out that liberalization was - in some unobserved ways - influenced by firms or accompanied by other policies. Hence we interpret our results as robust correlations rather than causal effects. It is, however, noteworthy that any endogeneity would make it more difficult to observe the patterns we see in the data. In particular, policymakers are less likely to lower tariffs in sectors struggling because of financial constraints.

\subsubsection{Findings for Market Exit}

In a first step, we examine the joint effects of trade liberalization and credit constraints on market exit. As explained earlier, we add a measure for the degree of competition to the list of control variables because it is one of the key drivers of market exit. In all regressions we apply the weak definition of market exit which includes firms that could not be contacted for reasons that indicate business failure. ${ }^{15}$ The estimation results are shown in the first two columns of Table 4.

- Table 4 about here -

Our estimates suggest that a tariff reduction among firms facing credit constraints in the initial period led to increased market exit. Reducing tariff protection by one percentage point for these firms is associated with a 0.6 percentage point increase in the probability of leaving the market. Larger tariff cuts are associated with increasing effects as indicated by the significant coefficient on the squared term. This is in line with the idea that firms can absorb small shocks but leave the market in case of large disruptions.

\subsubsection{Findings for Quality Upgrading}

For those firms who do not leave the market, we expect to see a negative effect of liberalization on credit-constrained firms' propensity to develop innovative products and production processes. We provide the respective regressions in columns 3-8 of Table 4 . Concerning

\footnotetext{
${ }^{14}$ With very few exceptions, none of the industry dummy variables shows a significant coefficient. Not surprisingly, however, most of the country dummy variables are significant.

${ }^{15}$ Only 62 firms (or three percent) left the market due to a recorded business failure according to the strict definition. Using the weak definition, 305 firms (or 14 percent) exit because of business failure or unaccounted reasons.
} 
the impact of tariff reductions itself we find some (weak) evidence of a positive impact on R\&D-related activities. This is in line with previous research (Lileeva and Trefler, 2010; Bustos, 2011b). The more important finding for our study, however, is the effect of trade liberalization on credit-constrained firms. Irrespective of which R\&D measure we use as outcome variable, we observe a significant negative coefficient on the interaction term of trade liberalization and credit constraints. The significance of the coefficients is also present and in some cases even larger in magnitude - when adding country-fixed effects to control for unobserved factors. Estimation results suggest that a one percentage point decrease in tariff protection reduces constrained firms' probability of being innovative by about twelve percentage points. Moreover, the probability of filing a patent is reduced by three to four percentage points among these firms. Unlike in the case of market exit (columns 1 and 2), there is only mixed evidence of a non-linear effect of larger tariff cuts. This may, however, be due to the limited number of observations in the last four regressions.

Overall, these findings support our theoretical predictions and suggest that limited access to finance not only distorts exporting behavior - as has been shown in previous research but also correlates with R\&D-related activities at the firm level.

\subsection{Alternative Explanations and Robustness Tests}

In order to verify our empirical findings we conduct a number of robustness tests. First, we examine whether the estimates are robust to changes in the econometric approach. Second, we address potential conceptual concerns.

Industry-Specific Differences - Following prior research by Rajan and Zingales (1998), we take into account the idea that different industries rely differently on external finance. As a result, firms in sectors with high dependence on external funding are more vulnerable to capital market frictions. We address this by adding industry-fixed effects to the right-hand side of equation 7 .

- Table 5 about here -

Estimates in Panel A of Table 5 show that when adding dummy variables for each industry, we still obtain coefficients on the interaction term of credit constraints and trade liberalization that are similar to those in our main estimation. 
Due to the small sample size adding many fixed effects, however, may be problematic. With data from seven countries and more than forty industries, we lose several degrees of freedom in the most demanding regression. Therefore we run a conditional (fixed-effects) logistic regression to test whether our estimates are robust (Chamberlain, 1980). Results in Panel B indicate that for all four outcome variables we still observe similar coefficients.

Small Firms - It is a well-known observation that a firm's size is strongly related to its probability of being financially constrained. In fact, our model predicts that poorer entrepreneurs run smaller firms and face more difficulties in terms of access to credit. Not surprisingly, this association is supported by the data. The status of being financially constrained is more prevalent among small firms. The numbers indicate that small firms are 36 percent more likely to be credit-constrained than large firms. Moreover there is evidence of serial correlation in the sense that firms reporting credit constraints in 2006 are much more likely to do so in 2010. The fact that firm size and access to credit are correlated may cause a problem for our empirical analysis. It could be argued that our dummy variable for being credit constrained $\left(A_{j, i, c, t-1}\right)$ captures other characteristics of small firms. If so, the effects reported above may not (solely) be driven by the importance of financial frictions.

We address this concern by running a 'horse race' between access to credit and being a small firm. In particular, we use a dummy variable for being a small firm in 2006 and use it in the same way as our indicator of being credit constrained. In case it is indeed access to finance which determines firms' behavior, only the interaction term with credit constraints should turn out to be significant. The results in Panel $\mathrm{C}$ of Table 5 show that the interaction terms with the small-firm dummy are insignificant while the credit constrained dummies remain significant. We take this as evidence that it is indeed access to credit causing differential responses to trade liberalization.

Weighted Average Tariff Rates - Another robustness test concerns the measure of trade liberalization. Throughout our estimations we used the simple average tariff rate at the four digit ISIC code to determine whether firms were subject to a reduction in tariff protection. In Panel D of Table 5 we instead use the weighted average tariff rate. Overall, the results are very similar to our baseline estimates. 
Heterogeneous Financial Development - The countries in our sample differ substantially with respect to their economic development. We expect to see the impact of credit constraints and tariff reductions to be magnified if capital market imperfections are more severe. In our model this would refer to a decrease in $\lambda$, the parameter governing the degree of imperfection of the capital market. To test this we split our sample and run the same regressions as before using only firms from less developed countries. Drawing on data from the International Monetary Fund, the GDP per capita (PPP) as of 2013 differs substantially among the seven countries of our sample: Argentina $\$ 22^{\prime} 300$, Bolivia $\$ 5 ’ 900$, Chile $\$ 22 ’ 500$, Colombia $\$ 12^{\prime} 800$, Paraguay $\$ 8^{\prime} 000$, Peru $\$ 11^{\prime} 600$, Uruguay $\$ 19^{\prime} 700$. We can use this information and restrict the sample to firms in Bolivia, Colombia, Paraguay and Peru. This leaves us with roughly half the number of observations. Note that in our survey data from the World Bank, firms located in Colombia and Paraguay are most likely to report difficulties getting access to credit. This supports the use of income per capita as a proxy for the development of a country's financial sector.

- Table 6 about here -

Results shown in Table 6 generally support our hypothesis. The point estimates for the joint impact of credit constraints and tariff cuts are larger in the restricted sample. Significance levels, however, are obviously lower given the substantial reduction in the number of observations.

Financial Crisis - A final concern we address is the impact of the global financial crisis of 2007-2008. Since we employ data from the years 2006 and 2010, the question arises how the crisis affects our empirical findings. In our empirical analysis we explore the differential impact of trade liberalization among firms that faced credit constraints in 2006 and those who did not. Thus we define treatment and control group based on firm characteristics determined before the stock market crash. The shock to the financial system in 2007, however, affected the countries in our sample. We can illustrate this by considering annual growth rates of real GDP. The numbers in Table 9 of the appendix show that on average the annual growth rate in 2008 and 2009 was three percentage points lower than in the two years before the financial crisis.

The heterogeneity across countries, however, does not affect our empirical findings as we add country fixed effects to the regression. Moreover, if trade policy was affected by the 
financial crises the most plausible bias would make it more difficult to observe the patterns in the data that we document: Policymakers are less likely to lower tariffs for firms in sectors that are vulnerable to shocks in the capital market.

\section{Conclusion}

In this study we explore heterogeneous responses to trade liberalization at the industry and firm level. As illustrated by a simple theoretical model, we expect financially constrained firms to have a higher probability of leaving the market after liberalization. For surviving firms, the model suggests limited investments in quality-upgrading when firms are financially constrained and face tariff cuts. Using firm level survey data from seven Latin American countries for the period from 2006 to 2010, we examine these predictions empirically. In line with our theory, we find that financially constrained firms being subject to liberalization are associated with more market exits, less product and process innovations, and less filed patents. This impact is shown to be robust to the inclusion of various control variables as well as country- and industry-fixed effects. Moreover, the findings are not driven by any single country or the specification of our regression equation. Instead the impact is generally magnified in less developed countries.

Our results add another dimension to the evidence on how financial constraints affect and distort firm behavior. In the presence of imperfect capital markets, adjustments after trade liberalization are limited at the firm level. As a result, gains from openness can be reduced in developing countries. This adds to the recent literature arguing that low aggregate total factor productivity - especially in developing countries - is the result of a resource misallocation at the firm level (Hsieh and Klenow, 2009; Song, Storesletten and Zilibotti, 2011). In a broader sense our findings suggest that reductions in the magnitude of one distortion (here trade costs) do not necessarily lead to a welfare gain if there are other distortions in the economy (Bhagwati, 1971).

The findings of our study are linked to policy implications. In the presence of credit constraints adjustments at the firm level can be impaired. Hence optimal policies must take into account the fact that sectors differ in their reliance on external finance and therefore in their ability to adjust their production to a post-liberalization environment. The importance 
of credit constraints with respect to international trade has been emphasized by Manova, Wei and Zhang (2014). Their findings suggest that FDI can reduce liquidity constraints at the firm level. Moreover, firms' credit rating has been shown to affect their propensity to engage in international trade (Muûls, 2012).

There are a number of caveats to our conclusions. First and foremost, tariff reductions across sectors are typically non-random. As a result, identifying causal effects of trade liberalization at the firm level remains challenging. We provide empirical evidence showing that firm characteristics such as size and age in the initial period do not correlate significantly with subsequent tariff changes. In addition, firms with credit constraints before trade policy changes were not more likely to be subject to trade liberalization. Moreover, we add countryand industry-fixed effects to control for unobserved factors. All of this does not affect our empirical findings. Regarding the magnitude of welfare gains from trade, however, Dehejia and Panagariya (2014) suggest that there may be positive spillover effects from liberalization in manufacturing to gross value added, wages, employment, and worker productivity in services. Hence, exploring firms' decision to move from manufacturing to service as a response to trade liberalization appears to be a promising field for future research. 


\section{References}

Acemoglu, Daron, and Fabrizio Zilibotti. 2001. "Productivity Differences." The Quarterly Journal of Economics, 116(2): 563-606.

Aghion, Philippe, Eve Caroli, and Cecilia García-Peñalosa. 1999. "Inequality and Economic Growth: The Perspective of the New Growth Theories." Journal of Economic Literature, 37(4): 1615-1660.

Aghion, Philippe, George-Marios Angeletos, Abhijit Banerjee, and Kalina Manova. 2010. "Volatility and growth: Credit constraints and the composition of investment." Journal of Monetary Economics, 57(3): 246-265.

Ai, Chunrong, and Edward C. Norton. 2003. "Interaction terms in logit and probit models." Economics Letters, 80(1): 123-129.

Amiti, Mary, and David E. Weinstein. 2011. "Exports and Financial Shocks." The Quarterly Journal of Economics, 126(4): 1841-1877.

Antras, Pol, and Ricardo J. Caballero. 2009. "Trade and Capital Flows: A Financial Frictions Perspective." Journal of Political Economy, 117(4): 701-744.

Arkolakis, Costas, Arnaud Costinot, and Andrés Rodríguez-Clare. 2012. "New Trade Models, Same Old Gains?" American Economic Review, 102(1): 94-130.

Atkeson, Andrew, and Ariel Tomas Burstein. 2010. "Innovation, Firm Dynamics, and International Trade." Journal of Political Economy, 118(3): 433-484.

Aw, Bee Yan, Mark J. Roberts, and Daniel Yi Xu. 2011. "R\&D Investment, Exporting, and Productivity Dynamics." American Economic Review, 101(4): 1312-1344.

Aw, Bee Yan, Mark J. Roberts, and Tor Winston. 2007. "Export Market Participation, Investments in R\&D and Worker Training, and the Evolution of Firm Productivity." The World Economy, 30(1): 83-104.

Banerjee, Abhijit V. 2004. "Contracting constraints, credit markets, and economic development." In Advances in Economics and Econometrics: Theory and Applications., ed. M. Dewatripoint, L. Hansen and S. Turnovsky. Cambridge:Cambridge University Press.

Banerjee, Abhijit V., and Esther Duflo. 2013. "Do Firms Want to Borrow More? Testing Credit Constraints Using a Directed Lending Program." Review of Economic Studies, forthcoming.

Bernard, Andrew B., and J. Bradford Jensen. 1999. "Exceptional exporter performance: cause, effect, or both?" Journal of International Economics, 47(1): 1-25.

Bernard, Andrew B., J. Bradford Jensen, and Peter K. Schott. 2006. "Trade costs, firms and productivity." Journal of Monetary Economics, 53(5): 917-937.

Bernard, Andrew B., J. Bradford Jensen, Stephen J. Redding, and Peter K. Schott. 2007. "Firms in International Trade." Journal of Economic Perspectives, 21(3): 105-130.

Bhagwati, Jagdish N. 1971. "The Generalized Theory of Distortions and Welfare." In Trade, balance of payments and growth., ed. Jagdish N. Bhagwati, Ronald Jones, Robert Mundell and Jaroslav Vanek, 69-90. Amsterdam:North Holland.

Bustos, Paula. 2011a. "The Impact of Trade Liberalization on Skill Upgrading: Evidence from Argentina."

Bustos, Paula. 2011b. "Trade Liberalization, Exports, and Technology Upgrading: Evidence on the Impact of MERCOSUR on Argentinian Firms." American Economic Review, 101(1): 304-340.

Caliendo, Lorenzo, and Esteban Rossi-Hansberg. 2012. "The Impact of Trade on Organization and Productivity." The Quarterly Journal of Economics, 127(3): 1393-1467. 
Caselli, Mauro. 2012. "Does wealth inequality reduce the gains from trade?" Review of World Economics, 148(2): 333-356.

Caselli, Mauro. 2013. "Credit constraints, inequality and the growth gains from trade." Economics Letters, 121(1): 43-47.

Chamberlain, Gary. 1980. "Analysis of Covariance Data with Qualitative." The Review of Economic Studies, 47(1): 225-238.

Chesnokova, Tatyana. 2007. "Immiserizing deindustrialization: A dynamic trade model with credit constraints." Journal of International Economics, 73(2): 407-420.

Costantini, James A., and Marc J. Melitz. 2008. "The Dynamics of Firm-Level Adjustment to Trade Liberalization." In The Organization of Firms in a Global Economy. , ed. Elhanan Helpman, Dalia Marin and Thierry Verdier, 107-141. Cambridge, MA:Harvard University Press.

Dehejia, Rajeev, and Arvind Panagariya. 2014. "Trade Liberalization in Manufacturing and Accelerated Growth in Services in India." NBER Working Paper \#19923.

Eaton, Jonathan, and Samuel Kortum. 2002. "Technology, Geography, and Trade." Econometrica, 70(5): 1741-1779.

Eaton, Jonathan, and Samuel Kortum. 2012. "Putting Ricardo to Work." The Journal of Economic Perspectives, 26(2): 65-90.

Epifani, Paolo, and Gino Gancia. 2011. "Trade, markup heterogeneity and misallocations." Journal of International Economics, 83(1): 1-13.

Fernandes, Ana M., and Caroline Paunov. 2013. "Does trade stimulate product quality upgrading?" Canadian Journal of Economics, 46(4): 1232-1264.

Fernandes, Ana M., and Caroline Paunov. 2014. "The Risks of Innovation: Are Innovating Firms Less Likely to Die?" Review of Economics and Statistics, forthcoming.

Fieler, Ana Cecilia, Marcela Eslava, and Daniel Xu. 2014. "Trade, Skills, and Quality Upgrading: A Theory with Evidence from Colombia." NBER Working Paper \#19992.

Foley, C. Fritz, and Kalina Manova. 2014. "International Trade, Multinational Activity, and Corporate Finance." Annual Review of Economics, forthcoming.

Föllmi, Reto, and Manuel Oechslin. 2010. "Market Imperfections, Wealth Inequality, and the Distribution of Trade Gains." Journal of International Economics, 81(1): 15-25.

Föllmi, Reto, and Manuel Oechslin. 2013. "Globalization and Productivity in the Developing World."

Galor, Oded, and Andrew Mountford. 2008. "Trading Population for Productivity: Theory and Evidence." The Review of Economic Studies, 75: 1143-1179.

Goldberg, Pinelopi K., and Nina Pavcnik. 2007. "Distributional Effects of Globalization in Developing Countries." Journal of Economic Literature, 45(1): 39-82.

Gorodnichenko, Yuriy, and Monika Schnitzer. 2013. "Financial Constraints and Innovation: Why Poor Countries Don't Catch Up." Journal of the European Economic Association, 11(5): 1115-1152.

Greenaway, David, Wyn Morgan, and Peter Wright. 2002. "Trade liberalisation and growth in developing countries." Journal of Development Economics, 67(1): 229-244.

Hsieh, Chang-Tai, and Peter J. Klenow. 2009. "Misallocation and Manufacturing TFP in China and India." The Quarterly Journal of Economics, 124(4): 1403-1448.

Lileeva, Alla, and Daniel Trefler. 2010. "Improved Access to Foreign Markets Raises Plant-level Productivity. . For Some Plants." The Quarterly Journal of Economics, 125(3): 1051-1099. 
Manova, Kalina. 2013. "Credit Constraints, Heterogeneous Firms, and International Trade." The Review of Economic Studies, 80(2): 711-744.

Manova, Kalina, Shang-Jin Wei, and Zhiwei Zhang. 2014. "Firm Exports and Multinational Activity Under Credit Constraints." Review of Economics and Statistics, forthcoming.

Melitz, Marc J. 2003. "The Impact of Trade on Intra-Industry Reallocations and Aggregate Industry Productivity." Econometrica, 71(6): 1695-1725.

Melitz, Marc J., and Gianmarco I. P. Ottaviano. 2008. "Market Size, Trade, and Productivity." Review of Economic Studies, 75(1): 295-316.

Melitz, Marc J., and Stephen J. Redding. 2014. "Missing Gains from Trade?" NBER Working Paper \#19810.

Muûls, Mirabelle. 2012. "Exporters, Importers and Credit Constraints." CEP Discussion Paper No 1169.

Norton, Edrvard C., Hua Wang, and Chunrong Ai. 2004. "Computing interaction effects and standard errors in logit and Probit models." The Stata Journal, 4(2): 154-167.

Rajan, Raghuram G., and Luigi Zingales. 1998. "Financial Dependence and Growth." The American Economic Review, 88(3): 559-586.

Schmookler, Jacob. 1966. Invention and Economic Growth. Cambridge:Harvard University Press.

Song, Zheng, Kjetil Storesletten, and Fabrizio Zilibotti. 2011. "Growing Like China." The American Economic Review, 101(2): 196-233.

Verhoogen, Eric A. 2008. "Trade, Quality Upgrading, and Wage Inequality in the Mexican Manufacturing Sector." The Quarterly Journal of Economics, 123(2): 489-530. 


\section{Figures and Tables}

Figure 1: Entrepreneurial Decisions by Endowment

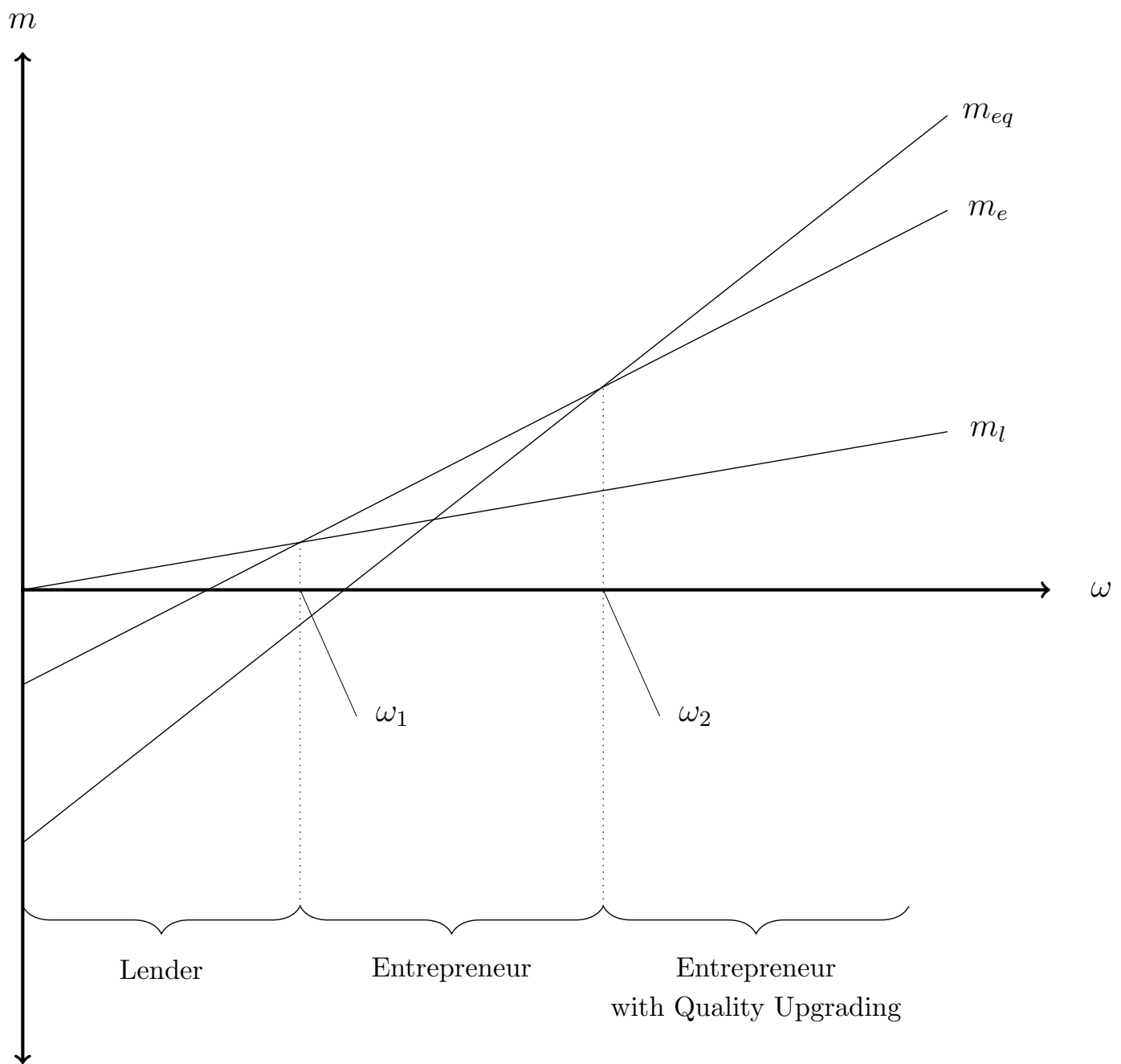

Note: The figure illustrates cutoff values for $\omega$ which determine whether individuals become lenders and receive a nominal income of $m_{l}$, become entrepreneurs $\left(m_{e}\right)$ or become entrepreneur and invest in quality upgrading $\left(m_{e q}\right)$. Individuals with an initial endowment below $\omega_{1}$ choose to become lenders while those with a larger endowment become entrepreneurs. If the initial endowment is larger than $\omega_{2}$, individuals become entrepreneurs and invest in quality upgrading. 
Table 1: Summary Statistics - Panel Sample

\begin{tabular}{lcccccccc}
\hline & ARG & BOL & CHL & COL & PAR & PER & URY & Total \\
\hline Tariff 2006 & 11.85 & 6.91 & 2.14 & 15.25 & 8.21 & 13.80 & 11.15 & 9.91 \\
Tariff 2010 & 14.11 & 12.96 & 4.68 & 15.55 & 8.80 & 8.15 & 11.03 & 10.52 \\
Tariff Cut & -2.26 & -6.05 & -2.54 & -0.24 & -0.52 & 5.68 & 0.14 & -0.59 \\
Tariff Cut sq. & 29.63 & 92.22 & 6.72 & 1.89 & 3.07 & 59.64 & 0.67 & 22.43 \\
\hline Credit cons. 2006 & 0.13 & 0.10 & 0.12 & 0.10 & 0.18 & 0.09 & 0.07 & 0.11 \\
Credit cons. 2010 & 0.15 & 0.10 & 0.14 & 0.14 & 0.10 & 0.07 & 0.03 & 0.12 \\
\hline Market Exit & 0.00 & 0.00 & 0.00 & 0.00 & 0.00 & 0.00 & 0.00 & 0.00 \\
Product Innovation & 0.40 & 0.65 & 0.53 & 0.48 & 0.56 & 0.67 & 0.52 & 0.54 \\
Process Innovation & 0.33 & 0.55 & 0.50 & 0.42 & 0.59 & 0.79 & 0.55 & 0.52 \\
File Patent & 0.34 & 0.34 & 0.40 & 0.22 & 0.22 & 0.25 & 0.25 & 0.27 \\
\hline Small firm & 0.37 & 0.34 & 0.32 & 0.46 & 0.26 & 0.32 & 0.43 & 0.37 \\
Medium-size firm & 0.40 & 0.35 & 0.50 & 0.43 & 0.46 & 0.44 & 0.41 & 0.44 \\
Firm age & 31.51 & 26.10 & 32.27 & 19.49 & 26.18 & 23.57 & 33.02 & 28.07 \\
Foreign owner & 0.11 & 0.21 & 0.09 & 0.03 & 0.12 & 0.09 & 0.07 & 0.09 \\
Share foreign inputs & 0.25 & 0.46 & 0.40 & 0.24 & 0.45 & 0.36 & 0.47 & 0.34 \\
Direct importer & 0.55 & 0.66 & 0.54 & 0.30 & 0.61 & 0.55 & 0.61 & 0.52 \\
Exporter & 0.46 & 0.34 & 0.31 & 0.35 & 0.35 & 0.49 & 0.39 & 0.39 \\
Share of labor cost & 0.33 & 0.35 & 0.37 & 0.38 & 0.37 & 0.32 & 0.37 & 0.36 \\
Competition & 0.50 & 0.39 & 0.57 & 0.65 & 0.60 & 0.55 & 0.56 & 0.56 \\
\hline Employees & 123.36 & 79.00 & 82.21 & 62.87 & 84.09 & 133.05 & 46.05 & 94.22 \\
Log Annual sales & 13.97 & 13.16 & 14.16 & 13.23 & 13.49 & 13.89 & 13.58 & 13.79 \\
\hline Observations & 374 & 40 & 382 & 276 & 50 & 246 & 140 & 1,508 \\
\hline
\end{tabular}

Note: The table shows descriptive statistics (mean values) for the panel sample of firms which are surveyed in both 2006 and 2010. Tariff Cut is calculated as the four-digit ISIC level tariff in 2006 minus the tariff in 2010. Market exit is defined as business failure including businesses not found in 2010 . All three measures of R\&D are dummy variables for innovative activity in the three years prior to 2010 . 
Table 2: Tariff Cuts, Credit Constraints, and Annual Sales

\begin{tabular}{|c|c|c|c|c|}
\hline & \multicolumn{2}{|c|}{ Constrained 2010} & \multicolumn{2}{|c|}{ Log Sales 2010} \\
\hline & (1) & $(2)$ & $(3)$ & (4) \\
\hline Tariff Cut & $\begin{array}{c}-0.004 \\
(0.003)\end{array}$ & $\begin{array}{c}-0.002 \\
(0.006)\end{array}$ & $\begin{array}{c}-0.015^{* *} \\
(0.005)\end{array}$ & $\begin{array}{c}-0.032^{* * *} \\
(0.004)\end{array}$ \\
\hline Tariff Cut sq. & $\begin{array}{c}0.001^{*} \\
(0.000)\end{array}$ & $\begin{array}{c}0.001^{* *} \\
(0.000)\end{array}$ & $\begin{array}{c}-0.001^{* * *} \\
(0.000)\end{array}$ & $\begin{array}{c}-0.001^{* * *} \\
(0.000)\end{array}$ \\
\hline Constrained 2006 & $\begin{array}{c}0.179^{* *} \\
(0.051)\end{array}$ & $\begin{array}{c}0.181^{* *} \\
(0.056)\end{array}$ & & \\
\hline Log Sales 2006 & & & $\begin{array}{c}0.638^{* * *} \\
(0.066)\end{array}$ & $\begin{array}{c}0.615^{* * *} \\
(0.080)\end{array}$ \\
\hline Sample & $\begin{array}{r}\text { small } \\
\text { siz }\end{array}$ & $\begin{array}{l}\text { medium } \\
\text { irms }\end{array}$ & $\begin{array}{l}\text { credit cc } \\
\text { firms }\end{array}$ & $\begin{array}{l}\text { istrained } \\
2006\end{array}$ \\
\hline Controls & Yes & Yes & Yes & Yes \\
\hline Country FE & Yes & Yes & Yes & Yes \\
\hline Industry FE & - & Yes & - & Yes \\
\hline Observations & 1,143 & 1,143 & 311 & 311 \\
\hline R-squared & 0.085 & 0.101 & 0.739 & 0.751 \\
\hline
\end{tabular}

Note: The table shows four separate regressions using different dependent variables as indicated in the top row. Standard errors are clustered at the country level and shown in parentheses. Significance levels are as follows: ${ }^{*} 0.10,{ }^{* *} 0.05$, *** 0.01 .

Table 3: Testing Tariff Changes for Endogeneity

\begin{tabular}{|c|c|c|c|c|}
\hline & \multicolumn{4}{|c|}{ Tariff Cut } \\
\hline & (1) & $(2)$ & $(3)$ & $(4)$ \\
\hline \multirow[t]{2}{*}{ Firm Size 2006} & 0.142 & -0.551 & -0.229 & 0.071 \\
\hline & $(0.286)$ & $(0.584)$ & $(0.522)$ & $(0.103)$ \\
\hline \multirow[t]{2}{*}{ Firm Age 2006} & 0.001 & -0.003 & -0.016 & -0.001 \\
\hline & $(0.015)$ & $(0.014)$ & $(0.014)$ & $(0.007)$ \\
\hline \multirow[t]{2}{*}{ Foreign Ownership 2006} & 0.224 & -0.136 & -0.716 & -0.295 \\
\hline & $(0.818)$ & $(1.115)$ & $(1.050)$ & $(0.502)$ \\
\hline \multirow[t]{2}{*}{ Annual Sales 2006} & & 0.402 & 0.154 & 0.077 \\
\hline & & $(0.541)$ & $(0.439)$ & $(0.151)$ \\
\hline \multirow[t]{2}{*}{ Exporter 2006} & & -0.153 & 0.496 & -0.111 \\
\hline & & $(0.629)$ & $(0.451)$ & $(0.571)$ \\
\hline \multirow[t]{2}{*}{ Credit Constrained 2006} & & -0.266 & -0.276 & -0.099 \\
\hline & & $(0.324)$ & $(0.209)$ & $(0.134)$ \\
\hline Industry FE & - & - & Yes & Yes \\
\hline Country FE & - & - & - & Yes \\
\hline Observations & 2,971 & 2,969 & 2,969 & 2,969 \\
\hline R-squared & 0.001 & 0.011 & 0.147 & 0.568 \\
\hline
\end{tabular}


Table 4: Main Results for Exit and Innovation

\begin{tabular}{lccccccccc}
\hline & \multicolumn{2}{c}{ Exit } & \multicolumn{2}{c}{ Innovate Product } & \multicolumn{2}{c}{ Innovate Process } & \multicolumn{2}{c}{ File Patent } \\
\cline { 2 - 10 } & $(1)$ & $(2)$ & $(3)$ & $(4)$ & $(5)$ & $(6)$ & $(7)$ & $(8)$ \\
\hline Tariff Cut & -0.001 & -0.001 & 0.006 & 0.001 & 0.008 & 0.015 & $0.009^{*}$ & 0.005 \\
& $(0.002)$ & $(0.001)$ & $(0.005)$ & $(0.003)$ & $(0.006)$ & $(0.010)$ & $(0.005)$ & $(0.009)$ \\
Tariff Cut sq. & 0.000 & $0.000^{* * *}$ & 0.000 & -0.000 & $0.002^{* * *}$ & $0.001^{* * *}$ & 0.001 & 0.001 \\
& $(0.000)$ & $(0.000)$ & $(0.000)$ & $(0.000)$ & $(0.001)$ & $(0.000)$ & $(0.000)$ & $(0.000)$ \\
Credit Constrained & 0.063 & $0.070^{*}$ & $0.167^{* *}$ & $0.157^{* *}$ & -0.210 & -0.069 & -0.041 & -0.020 \\
& $(0.044)$ & $(0.046)$ & $(0.063)$ & $(0.070)$ & $(0.191)$ & $(0.169)$ & $(0.055)$ & $(0.061)$ \\
CC x Tariff Cut & $0.005^{* *}$ & 0.005 & $-0.099^{* *}$ & $-0.104^{* *}$ & $-0.110^{*}$ & $-0.101^{* *}$ & $-0.029^{*}$ & $-0.043^{* *}$ \\
& $(0.003)$ & $(0.003)$ & $(0.043)$ & $(0.046)$ & $(0.065)$ & $(0.055)$ & $(0.019)$ & $(0.020)$ \\
CC x Tariff Cut sq. & $0.001^{* * *}$ & $0.001^{* * *}$ & $-0.017^{* * *}$ & $-0.018^{* * *}$ & -0.038 & -0.031 & -0.010 & -0.013 \\
& $(0.000)$ & $(0.000)$ & $(0.006)$ & $(0.006)$ & $(0.050)$ & $(0.044)$ & $(0.007)$ & $(0.008)$ \\
\hline Controls & Yes & Yes & Yes & Yes & Yes & Yes & Yes & Yes \\
Country FE & - & Yes & - & Yes & - & Yes & - & Yes \\
\hline R-squared & 0.06 & 0.11 & 0.05 & 0.08 & 0.05 & 0.10 & 0.09 & 0.09 \\
Observations & 1025 & 1025 & 236 & 236 & 197 & 197 & 361 & 361 \\
\hline
\end{tabular}

Note: The table shows eight separate Probit regressions using the full sample and different dependent variables as indicated in the top row. Coefficients show marginal effects at the means of covariates. Standard errors are clustered at the country level and shown in parentheses. Significance levels are as follows: ${ }^{*} 0.10,{ }^{* *} 0.05,{ }^{* * *} 0.01$. 
Table 5: Robustness and Specification Tests

\begin{tabular}{|c|c|c|c|c|}
\hline & Exit & Innovate Product & Innovate Process & File Patent \\
\hline & $(1)$ & $(2)$ & $(3)$ & $(4)$ \\
\hline \multicolumn{5}{|l|}{ A: Country and Industry Fixed Effects } \\
\hline Credit Constrained $\mathrm{x}$ Tariff Cut & $\begin{array}{l}0.006^{*} \\
(0.003)\end{array}$ & $\begin{array}{c}-0.089 \\
(0.060)\end{array}$ & $\begin{array}{c}-0.101^{*} \\
(0.070)\end{array}$ & $\begin{array}{c}-0.055^{* *} \\
(0.028)\end{array}$ \\
\hline Credit Constrained x Tariff Cut sq. & $\begin{array}{c}0.001^{* * *} \\
(0.000)\end{array}$ & $\begin{array}{c}-0.015^{* *} \\
(0.007)\end{array}$ & $\begin{array}{l}-0.037 \\
(0.048)\end{array}$ & $\begin{array}{c}-0.013 \\
(0.009)\end{array}$ \\
\hline Observations & 1008 & 220 & 193 & 352 \\
\hline \multicolumn{5}{|l|}{ B: Conditional Logit Estimation } \\
\hline Credit Constrained $\mathrm{x}$ Tariff Cut & $\begin{array}{c}0.008 \\
(0.008)\end{array}$ & $\begin{array}{c}-0.672^{* * *} \\
(0.274)\end{array}$ & $\begin{array}{c}-0.144^{*} \\
(0.086)\end{array}$ & $\begin{array}{l}-0.217 \\
(0.151)\end{array}$ \\
\hline Credit Constrained x Tariff Cut sq. & $\begin{array}{c}0.001^{* * *} \\
(0.000)\end{array}$ & $\begin{array}{c}-0.097^{* *} \\
(0.029)\end{array}$ & $\begin{array}{l}-0.044 \\
(0.074)\end{array}$ & $\begin{array}{l}-0.092^{*} \\
(0.050)\end{array}$ \\
\hline Observations & 1025 & 236 & 197 & 361 \\
\hline \multicolumn{5}{|c|}{ C: Horse Race against Small Firms $x$ Tariff Cut } \\
\hline Credit Constrained $\mathrm{x}$ Tariff Cut & $\begin{array}{c}0.004 \\
(0.005)\end{array}$ & $\begin{array}{c}-0.109^{* * *} \\
(0.045)\end{array}$ & $\begin{array}{c}-0.105^{* *} \\
(0.054)\end{array}$ & $\begin{array}{c}-0.046^{* * *} \\
(0.021)\end{array}$ \\
\hline Credit Constrained x Tariff Cut sq. & $\begin{array}{c}0.001^{* * *} \\
(0.000)\end{array}$ & $\begin{array}{c}-0.017^{* * *} \\
(0.006)\end{array}$ & $\begin{array}{l}-0.032 \\
(0.044)\end{array}$ & $\begin{array}{l}-0.012 \\
(0.008)\end{array}$ \\
\hline Observations & 1025 & 236 & 197 & 361 \\
\hline \multicolumn{5}{|l|}{ D: Weighted Average Tariff Rates } \\
\hline Credit Constrained $\mathrm{x}$ Tariff Cut & $\begin{array}{c}0.011^{* * *} \\
(0.004)\end{array}$ & $\begin{array}{c}-0.027^{*} \\
(0.015)\end{array}$ & $\begin{array}{c}-0.113^{* *} \\
(0.057)\end{array}$ & $\begin{array}{c}-0.072^{* * *} \\
(0.026)\end{array}$ \\
\hline Credit Constrained x Tariff Cut sq. & $\begin{array}{c}0.001^{* * *} \\
(0.000)\end{array}$ & $\begin{array}{l}-0.003 \\
(0.002)\end{array}$ & $\begin{array}{c}-0.015^{* * *} \\
(0.006)\end{array}$ & $\begin{array}{c}-0.004^{* *} \\
(0.002)\end{array}$ \\
\hline Observations & 1008 & 220 & 193 & 352 \\
\hline
\end{tabular}

Note: The table shows sixteen separate Probit regressions using different dependent variables as indicated in the top row. Coefficients show marginal effects at the means of covariates. All estimations include country fixed effects. Standard errors are clustered at the country level and shown in parentheses. Significance levels are as follows: ${ }^{*} 0.10,{ }^{* *} 0.05,{ }^{* * *} 0.01$. 
Table 6: Effect on Exit and Innovation in Less Developed Counties

\begin{tabular}{lccccccccc}
\hline & \multicolumn{2}{c}{ Exit } & \multicolumn{3}{c}{ Innovate Product } & \multicolumn{2}{c}{ Innovate Process } & \multicolumn{2}{c}{ File Patent } \\
\cline { 2 - 10 } & $(1)$ & $(2)$ & $(3)$ & $(4)$ & $(5)$ & $(6)$ & $(7)$ & $(8)$ \\
\hline Tariff Cut & $-0.006^{* * *}$ & -0.001 & 0.009 & 0.011 & -0.017 & $-0.029^{*}$ & -0.006 & -0.020 \\
& $(0.002)$ & $(0.001)$ & $(0.015)$ & $(0.016)$ & $(0.016)$ & $(0.015)$ & $(0.007)$ & $(0.016)$ \\
Tariff Cut sq. & -0.000 & $0.000^{* * *}$ & 0.000 & -0.000 & $0.004^{* *}$ & $0.004^{* * *}$ & $0.001^{* *}$ & $0.002^{* * *}$ \\
& $(0.000)$ & $(0.000)$ & $(0.001)$ & $(0.001)$ & $(0.002)$ & $(0.001)$ & $(0.001)$ & $(0.001)$ \\
Credit Constrained & 0.082 & $0.092^{*}$ & 0.097 & 0.041 & 0.162 & 0.102 & -0.063 & 0.020 \\
& $(0.067)$ & $(0.056)$ & $(0.148)$ & $(0.130)$ & $(0.272)$ & $(0.232)$ & $(0.135)$ & $(0.162)$ \\
CC x Tariff Cut & 0.006 & $0.008^{* * *}$ & -0.382 & $-0.401^{*}$ & -0.213 & -0.259 & -0.043 & -0.057 \\
& $(0.005)$ & $(0.004)$ & $(0.159)$ & $(0.148)$ & $(0.179)$ & $(0.132)$ & $(0.048)$ & $(0.049)$ \\
CC x Tariff Cut sq. & $0.001^{* * *}$ & $0.001^{* * *}$ & 0.269 & 0.343 & $-0.279^{* *}$ & $-0.278^{* * *}$ & -0.001 & -0.008 \\
& $(0.000)$ & $(0.000)$ & $(0.134)$ & $(0.121)$ & $(0.156)$ & $(0.079)$ & $(0.037)$ & $(0.343)$ \\
\hline Controls & Yes & Yes & Yes & Yes & Yes & Yes & Yes & Yes \\
Country FE & - & Yes & - & Yes & - & Yes & - & Yes \\
\hline R-squared & 0.07 & 0.09 & 0.10 & 0.14 & 0.11 & 0.15 & 0.15 & 0.17 \\
Observations & 546 & 546 & 116 & 116 & 111 & 111 & 180 & 180 \\
\hline
\end{tabular}

Note: The table shows eight separate Probit regressions using data from less developed countries (Bolivia, Colombia, Paraguay and Peru). Dependent variables are indicated in the top row. Coefficients show marginal effects at the means of covariates. Standard errors are clustered at the country level and shown in parentheses. Significance levels are as follows: ${ }^{*} 0.10,{ }^{* *} 0.05,{ }^{* * *} 0.01$. 


\section{Appendix - Not for Publication}

\section{Definition of Variables}

All information on firm characteristics are taken from the World Bank Enterprise Survey (WBES). Tariff data are taken from the World Integrated Trade Solution (WITS) database.

Below we provide details on how we constructed the variables for the empirical analysis.

Table 7: Variable Definitions and Data Sources

\begin{tabular}{lcc}
\hline Variable & Definition & Source \\
\hline $\begin{array}{l}\text { Tariff } \\
\text { Tariff cut }\end{array}$ & simple average level of nominal tariff protection & WITS \\
Tariff cut sq. & tariff rate in 2006 minus tariff rate 2010 & Wquared value of tariff cut \\
\hline Credit constrained & $=1$ if access to finance single most serious obstacle & WBES \\
\hline Market Exit & $=1$ if firm could not be surveyed in 2010 & WBES \\
Product Innovation & $=1$ if firm introduced new product in 2007-2010 & WBES \\
Process Innovation & 1 if firm introduced new production process in 2007-2010 & WBES \\
File Patent & $=1$ if firm applied or filed for any patent in 2007-2010 & WBES \\
\hline Small firm & $=1$ if 19 or less full-time employees & WBES \\
Medium-size firm & $=1$ if $20-99$ full-time employess & WBES \\
Firm age & years since operation began & WBES \\
Foreign owner & 1 if positive share is owned by foreign individuals / companies & WBES \\
Share foreign inputs & share of total material inputs of foreign origin & WBES \\
Direct importer & $=1$ if any material inputs are imported directly & WBES \\
Share of labor cost & wages, bonuses and social payments as share of total costs & WBES \\
Competition & 1 if more than 5 competitors in the market of main product & WBES \\
Employees & permanent full-time employees & WBES \\
Exporter & $=1$ if any revenue from direct or indirect exports & WBES \\
Log Annual sales & log total annual sales in 2006 USD & WBES \\
\hline
\end{tabular}

Note: When asked about the most serious obstacle, each firm was given a card with 16 different obstacles, including among others corruption, regulation, electricity, instability, taxes, or transportation. If the firm chose access to credit as the most serious obstacle, we code credit constrained as one. 


\section{Trade in Selected Countries}

The tables below provide details on imports and exports of the seven countries in our empirical part. Moreover we show the countries' real GDP growth during the financial crisis.

Table 8: Trade Statistics for Countries in Our Dataset

\begin{tabular}{|c|c|c|c|c|}
\hline Country & Main Importers & Main Exporters & Balance & Trade/GDP \\
\hline Argentina & $\begin{array}{l}\text { BRA (28), EU (17), } \\
\text { USA (15), CHN(12) }\end{array}$ & $\begin{array}{l}\text { BRA (21), EU (12), } \\
\text { CHN (7), USA (6) }\end{array}$ & 1,864 & 40.1 \\
\hline Bolivia & $\begin{array}{l}\text { BRA (17), CHN (14), } \\
\text { USA (13), EU (13) }\end{array}$ & $\begin{array}{l}\text { BRA (34), ARG (20), } \\
\text { USA (10), EU (7) }\end{array}$ & 237 & 74.6 \\
\hline Chile & $\begin{array}{l}\text { USA }(20), \text { CHN }(20), \\
\operatorname{EU}(16), \operatorname{BRA}(7)\end{array}$ & $\begin{array}{l}\text { CHN (25), EU (15), } \\
\text { USA (13), JPN (10) }\end{array}$ & 329 & 69.2 \\
\hline Colombia & $\begin{array}{l}\text { USA (28), CHN (17), } \\
\operatorname{EU}(13), \operatorname{MEX}(9)\end{array}$ & $\begin{array}{l}\text { USA (32), EU (16), } \\
\text { CHN (9), PAN (6) }\end{array}$ & $-1,806$ & 35.3 \\
\hline Paraguay & $\begin{array}{l}\text { CHN (29), BRA (27), } \\
\text { ARG }(14), \text { EU (8) }\end{array}$ & $\begin{array}{l}\text { BRA (30), EU (14), } \\
\text { RUS (10), ARG (9) }\end{array}$ & -627 & 100.2 \\
\hline Peru & $\begin{array}{l}\text { USA (25), CHN (15), } \\
\operatorname{EU}(11), \operatorname{BRA}(5)\end{array}$ & $\begin{array}{l}\text { USA (18), CHN (18), } \\
\operatorname{EU}(16), \operatorname{CAN}(7)\end{array}$ & $-1,777$ & 49.2 \\
\hline Uruguay & $\begin{array}{l}\text { CHN (17), EU (15), } \\
\text { BRA (15), ARG (14) }\end{array}$ & $\begin{array}{l}\mathrm{CHN}(22), \text { BRA }(17) \\
\mathrm{EU}(15), \operatorname{ARG}(5)\end{array}$ & 373 & 54.7 \\
\hline
\end{tabular}

Note: Information on trade partners and balance is as of 2013 and taken from the European Commission. Numbers in parentheses express shares in percent. The trade balance is expressed in million Euro. Data on the share of trade in GDP is as of 2012 and reported by the WTO.

Table 9: Financial Crisis in the Countries in Our Dataset

\begin{tabular}{lccccc}
\hline Country & \multicolumn{5}{c}{ Real GDP Growth } \\
& $\mathbf{2 0 0 6}$ & $\mathbf{2 0 0 7}$ & $\mathbf{2 0 0 8}$ & $\mathbf{2 0 0 9}$ & $\mathbf{2 0 1 0}$ \\
\hline Argentina & 8.4 & 8.0 & 3.1 & 0.1 & 9.1 \\
Bolivia & 4.8 & 4.6 & 6.1 & 3.4 & 4.1 \\
Chile & 4.4 & 5.2 & 3.3 & -1.0 & 5.8 \\
Colombia & 6.7 & 6.9 & 3.5 & 1.7 & 4.0 \\
Paraguay & 4.8 & 5.4 & 6.4 & -4.0 & 13.1 \\
Peru & 7.5 & 8.5 & 9.1 & 1.0 & 8.5 \\
Uruguay & 4.1 & 6.5 & 7.2 & 2.4 & 8.4 \\
\hline
\end{tabular}

Note: Information on GDP growth is taken from the World Bank database. Numbers indicate the annual change in percent while GDP is based on 2005 U.S. dollars. 